\title{
Local Action of Phosphate Depletion and Insulin-like Growth Factor 1 on In Vitro Production of 1,25-dihydroxyvitamin D by Cultured Mammalian Kidney Cells
}

\author{
Luce Condamine, Francois Vztovsnik, * Gérard Friedlander, ${ }^{*}$ Cheikh Menaa, and Michèle Garabédian \\ CNRS URA 583, Hôpital Saint Vincent de Paul, 75014 Paris, France; and *INSERM U 251, Faculté Xavier Bichat, \\ 75018 Paris, France
}

\begin{abstract}
The hormonal form of vitamin $D, 1,25(\mathrm{OH})_{2} D$, is synthesized mostly in proximal renal tubular cells. Experimental and clinical studies suggest that the growth hormone may be involved in growth-related fluctuations of plasma $1,25(\mathrm{OH})_{2} \mathrm{D}$ and in the increase of $1,25(\mathrm{OH})_{2} \mathrm{D}$ induced by in vivo phosphate deprivation, an action possibly mediated by insulin-like growth factor 1 (IGF 1 ). We tested the effects of phosphate depletion and IGF 1 addition on $1,25(\mathrm{OH})_{2} \mathrm{D}_{3}$ production in cultured kidney cells: opossum kidney (OK) cells, LLC-PK 1, and rabbit's proximal tubular cells.

Confluent cell monolayers were preincubated in various phosphate concentrations, in the presence and absence of IGF 1. Then, $5 \mathrm{nM}$ of $\left[{ }^{3} \mathrm{H}\right] 25(\mathrm{OH}) \mathrm{D}_{3}$ or $2 \mu \mathrm{M}$ of $25(\mathrm{OH}) \mathrm{D}_{3}$ were added to the medium and the cells were incubated for a further $120 \mathrm{~min}$. The amount of biosynthesized $1,25(\mathrm{OH})_{2} \mathrm{D}_{3}$ in lipid extracts was determined after two different straight phase high performance liquid chromatographies. The experiment showed the following: (a) LLCPK 1 and rabbit's cells expressed a detectable ability to synthesize $1,25(\mathrm{OH})_{2} \mathrm{D}_{3}$, while $\mathrm{OK}$ cells did not. (b) Partial or total phosphate deprivation increased the amount of $1,25(\mathrm{OH})_{2} \mathrm{D}_{3}$ produced, respectively in LLC-PK 1 and in rabbit's cells. (c) IGF $1(25 \mathrm{ng} / \mathrm{ml})$ increased $1,25(\mathrm{OH})_{2} \mathrm{D}_{3}$ production in rabbit's cells, particularly in phosphate-free medium (1.6-fold), and in LLC-PK 1 cells, in partial phosphate depletion (2.75-fold in $1 \mathrm{mM}$ phosphate, $P=0.015$, $n=5$, and 3.2-fold in $0.5 \mathrm{mM}$ phosphate, $P=0.043, n$ $=4)$. Our findings demonstrate a local action of phosphate depletion and of IGF 1 on 1,25-dihydroxyvitamin $D_{3}$ production (J. Clin. Invest. 1994. 94:1673-1679.) Key words: calcitriol • OK cells - LLC-PK 1 cells • rabbit's proximal tubular cells $\cdot$ somatomedin
\end{abstract}

\footnotetext{
This work was presented in part at the XIth International Conference on Calcium Regulating Hormones, Florence, Italy, April 24-29, 1992.

Address correspondence to Dr. M. Garabédian, CNRS URA 583, endocrinologie pédiatrique, Hôpital Saint Vincent de Paul, avenue Denfert Rochereau, 75014 Paris, France. 994.

Received for publication 1 June 1993 and in revised form 9 May
}

J. Clin. Invest.

(c) The American Society for Clinical Investigation, Inc.

0021-9738/94/10/1673/07 \$2.00

Volume 94, October 1994, 1673-1679

\section{Introduction}

The hormonal form of vitamin $\mathrm{D}, 1,25$-dihydroxyvitamin $\mathrm{D}$ $\left(1,25-[\mathrm{OH}]_{2} \mathrm{D}\right)$ is known to play an important role in bone mineralization during growth (1) and its circulating concentrations are the subject of fluctuations which are parallel to those of growth velocity (2-5). Physiologically, in nonpregnant mammalians, most of $1,25-(\mathrm{OH})_{2} \mathrm{D}$ synthesis takes place in proximal tubular cells $(6-10) .25-(\mathrm{OH}) \mathrm{D}_{3}-1 \alpha$ hydroxylase ( $1 \alpha$ OHase), responsible for this synthesis in the kidney, is known to be under the control of a series of modulators. Parathyroid hormone $(\mathrm{PTH}), 1,25-(\mathrm{OH})_{2} \mathrm{D}_{3}$, calcitonin, and extracellular concentrations of calcium and phosphate were first evidenced as modulators of this enzyme system (6-11). Phosphate is a particularly interesting regulator of $1 \alpha \mathrm{OHase}$ : in animals and in humans $(6,7,9,10,12,13)$, dietary phosphate restriction or low phosphate serum concentrations lead to an increase of plasma $1,25-(\mathrm{OH})_{2} \mathrm{D}$ concentration, but in vitro no direct effect of phosphate depletion on $1,25-(\mathrm{OH})_{2} \mathrm{D}_{3}$ production has so far been evidenced $(14,15)$. Moreover, in vivo, the adaptation of $1,25-(\mathrm{OH})_{2} \mathrm{D}_{3}$ production to phosphate depletion needs integrity of the hypothalamo-hypophysis axis (16-19).

None of the above mentioned regulating factors explains the evolution of $1,25-(\mathrm{OH})_{2} \mathrm{D}$ synthesis during growth. The plasma concentration of $1,25-(\mathrm{OH})_{2} \mathrm{D}$ is higher in children than in adults. But PTH is not elevated, calcium concentrations are not decreased, and phosphate concentrations are increased, and not decreased during childhood. Experimental and clinical studies suggest that the growth hormone $(\mathrm{GH})$ may be involved in these growth-related fluctuations of plasma $1,25-(\mathrm{OH})_{2} \mathrm{D}$, and in the plasma $1,25-(\mathrm{OH})_{2} \mathrm{D}$ increase induced by in vivo phosphate deprivation (16-19). This GH action may be mediated by the insulin-like growth factor 1 (IGF 1$)(20,21)$. However, the only influence of IGF 1 on $1 \alpha$ OHase activity evidenced in vitro was obtained at a pharmacological dose (22).

To have a better comprehension of the regulation of 1,25 $(\mathrm{OH})_{2} \mathrm{D}$ during growth, we tested the in vitro effects of phosphate deprivation and IGF 1 addition on $1 \alpha$ OHase activity in three different types of mammalian kidney cells in culture: opossum kidney (OK) ${ }^{1}$ cells, LLC-PK 1 , and rabbit's proximal tubular cells.

\section{Methods}

Materials. Ethanolamine, insulin, transferrin, dexamethasone, epidermal growth factor (EGF), retinoic acid, type I collagenase, sodium selenite

1. Abbreviation used in this paper: $\mathrm{OK}$, opossum kidney. 
and bovine serum albumin were purchased from Sigma Chemical Co. (St Louis, MO). Percoll was purchased from Pharmacia AB (Uppsala, Sweden). Culture media were from Eurobio (Paris, France), and reagents were from Flow Laboratories (Irvine, U.K.). Plasticware was from Falcon (Oxnard, CA).

1,25- $(\mathrm{OH})_{2} \mathrm{D}_{3}$ was a gift from Roche Laboratories (Basel, Switzerland), $\left[26,27-{ }^{3} \mathrm{H}\right] 25-(\mathrm{OH}) \mathrm{D}_{3}$ (specific activity $19 \mathrm{Ci} / \mathrm{mmol}$ ) and $\left[26,27-{ }^{3} \mathrm{H}\right] 1,25-(\mathrm{OH})_{2} \mathrm{D}_{3}$ (specific activity $110 \mathrm{Ci} / \mathrm{mmol}$ ) were purchased from Amersham (Amersham, U.K.) and unlabeled 25- $(\mathrm{OH}) \mathrm{D}_{3}$ was a gift from Roussel Laboratories (Paris, France). Chromatography solvents ( $n$-hexane, isopropranol, methylene chloride) were of HPLCgrade and purchased from Merck (Germany). Scintillation fluid was purchased from Packard Instruments (Downers Grove, $\mathrm{IL}$ ).

Insulin-like Growth Factor 1 (IGF 1) was human recombinant and purchased from Becton Dickinson Labware (France).

Kidney cell cultures. The cultured kidney monolayers used in this study were of three types: ( $a$ ) A renal cell line derived from an opossum kidney (OK) as originally established by Koyama et al. (23). The cells, between the 60th and 70th passages, were cultured in a DME-Ham F12 mixture containing L-glutamine, $2.5 \% \mathrm{FCS}, 50 \mathrm{IU} / \mathrm{ml}$ penicillin, and 50 $\mu \mathrm{g} / \mathrm{ml}$ streptomycin as previously described (24). All cultures were maintained at $37^{\circ} \mathrm{C}$ under $5 \% \mathrm{CO}_{2}$ in air. The cells were plated in $24-$ well plastic trays. They reached confluence within $4 \mathrm{~d}$. The assays were performed on day 5-6.

(b) LLC-PK 1 cells (passages 200-220, obtained from Flow Laboratories) were seeded in 24 -well plastic trays and grown at $37^{\circ} \mathrm{C}$ under $5 \%$ $\mathrm{CO}_{2}$ in a serum-free medium. The medium consisted of a $1: 1(\mathrm{vol} / \mathrm{vol})$ Ham's F-12 and DMEM supplemented as previously described (25).

(c) Primary cultures of rabbit's renal proximal tubular cells were prepared according to Bello-Reuss and Webber (26) with minor modifications (27). Kidneys were removed aseptically from anesthetized New Zealand rabbits, decapsulated and sliced in 1-mm-thick sections. Cortex was separated from medulla, cortical slices were rinsed and submitted to trypsine-collagenase digestion for 50-60 min. Then, the mixture of renal tubules was washed and centrifugated. Homogeneous populations of nephron segments were separated by Percoll centrifugation as described by Vinay et al. (28). The F4 layer, made of proximal tubules, was removed, suspended in HBS-Hepes, washed and centrifugated three times in this solution. The final pellet was suspended in the culture medium and tubules were seeded in 24-well plastic trays coated with $\mathrm{NH}_{3}$-reconstituted rat's tail collagen $\left(2.5 \times 10^{4}\right.$ fragments/well $)$ (29). The serum-free culture medium (30) consisted in a 1:1 ( vol/vol) Ham's F-12 and DME mixture supplemented with $5 \mu \mathrm{g} / \mathrm{ml}$ insulin, 35 $\mu \mathrm{g} / \mathrm{ml}$ transferrin, $10 \mathrm{ng} / \mathrm{ml}$ epithelial growth factor (EGF), $2.2 \mu \mathrm{M}$ retinoic acid, $20 \mu \mathrm{M}$ ethanolamine, and $50 \mathrm{nM}$ dexamethasone. Cells were first seeded with a medium containing $1 \%$ of fetal calf serum (FCS), and cultured after the third day in a serum-free medium.

Metabolism of 25-(OH)D3 by cells in vitro. On the day before the experiment, the culture medium was changed and the cells $(\sim 50,000$ cells/well) were preincubated for $16 \mathrm{~h}$ in $0.5 \mathrm{ml}$ of a hormone and phosphate free DMEM with or without $0.5,1$, or $2 \mathrm{mM} \mathrm{KH}_{2} \mathrm{PO}_{4}$ and with or without $25 \mathrm{ng} / \mathrm{ml}$ IGF 1 . There was no increase of cell protein concentration after the 16-h incubation with IGF 1.

To measure the ability of these cells to convert $25-(\mathrm{OH}) \mathrm{D}_{3}$ into $1,25-(\mathrm{OH})_{2} \mathrm{D}_{3}, 10 \mu \mathrm{l}$ of ethanol containing $50 \mathrm{nCi}\left[{ }^{3} \mathrm{H}\right] 25-(\mathrm{OH}) \mathrm{D}_{3}$ (final concentration, $5 \mathrm{nM}$ ) or $10 \mu \mathrm{l}$ of ethanol containing $0.4 \mu \mathrm{g} 25-$ $(\mathrm{OH}) \mathrm{D}_{3}$ (final concentration, $2 \mu \mathrm{M}$ ) were added to the medium and the incubation was continued for $120 \mathrm{~min}$. Cells and medium were then transferred to glass tubes and the reaction was terminated by a Bligh and Dyer (31) extraction: $1 \mathrm{ml}$ of HPLC grade methanol and $1 \mathrm{ml}$ of chloroform were added to each sample. The chloroform phase was dried under $\mathrm{N}_{2}$, and the residue redissolved in the chromatographic solvent. The samples were cochromatographed with either $100 \mathrm{ng}$ unlabeled $1,25-(\mathrm{OH})_{2} \mathrm{D}_{3}$, for radioactive cell extracts, or $3,000 \mathrm{dpm}\left[{ }^{3} \mathrm{H}\right] 1,25-$ $(\mathrm{OH})_{2} \mathrm{D}_{3}$, for unlabeled cell extracts, using a straight phase HPLC system and a $4.6 \times 250-\mathrm{mm}$ Ultrasphere $\mathrm{Si}$ column (Altex, Berkeley, CA), equilibrated with $n$-hexane:isopropanol (92:8, flow rate $1.5 \mathrm{ml} /$ $\mathrm{min}$ ). Absorbance at $254 \mathrm{~nm}$ was continuously monitored and fractions of the effluent were collected every $1 \mathrm{~min}$ for determination of radioactivity. Fractions co-eluting with synthetic $1,25-(\mathrm{OH})_{2} \mathrm{D}_{3}$ (or $\left[{ }^{3} \mathrm{H}\right] 1,25$ $[\mathrm{OH}]_{2} \mathrm{D}_{3}$ ) were pooled and rechromatographed as described above but using a methylene chloride:isopropanol (95:5, flow rate $1 \mathrm{ml} / \mathrm{min}$ ) solvent system. For incubations performed in the presence of $5 \mathrm{nM}\left[{ }^{3} \mathrm{H}\right] 25-$ $(\mathrm{OH}) \mathrm{D}_{3}$, the rate of conversion of $\left[{ }^{3} \mathrm{H}\right] 25-(\mathrm{OH}) \mathrm{D}_{3}$ into $\left[{ }^{3} \mathrm{H}\right] 1,25-$ $(\mathrm{OH})_{2} \mathrm{D}_{3}$ was determined by calculating the percentage of total radioactivity with an appropriate elution profile after the two successive chromatographies. Results are expressed as $\mathrm{fmol} / 10^{6}$ cells, based on the assumption that the specific activity of the product was the same as that of the substrate. Thus, conversion of $1 \%$ of the substrate into $\left[{ }^{3} \mathrm{H}\right] 1,25-$ $(\mathrm{OH})_{2} \mathrm{D}_{3}$ corresponds to the production of $25 \mathrm{fmol}$.

The purified $25-(\mathrm{OH}) \mathrm{D}_{3}$ metabolite produced during incubations of kidney cells with $2 \mu \mathrm{M}$ unlabeled $25-(\mathrm{OH}) \mathrm{D}_{3}$ was tested for its ability to bind to the $1,25-(\mathrm{OH})_{2} \mathrm{D}_{3}$ receptors present in chick intestinal cytosol using the radiocompetition binding assay used to measure plasma 1,25$(\mathrm{OH})_{2} \mathrm{D}(32)$.

The amount of $1,25-(\mathrm{OH})_{2} \mathrm{D}_{3}$ produced during the incubation with $0.4 \mu \mathrm{g} 25-(\mathrm{OH}) \mathrm{D}_{3}$ was calculated from the absorbance at $254 \mathrm{~nm}$ of the single peak co-eluting with synthetic $\left[{ }^{3} \mathrm{H}\right] 1,25-(\mathrm{OH})_{2} \mathrm{D}_{3}$ in the second HPLC sytem.

Ultraviolet (UV) absorption spectra of the purified metabolite were performed using a HPLC system fitted with a photodiode array detector (model 996; Millipore/Continental Water Systems, Saint Quentin en Yvelines, France), and compared with the spectrum of synthetic 1,25$(\mathrm{OH})_{2} \mathrm{D}_{3}$ (Millenium 2010).

Statistical methods. Statistical analyses were performed using the ttest or the Wilcoxon test for paired data, with and without phosphate depletion, with and without IGF 1, (Statworks; Microsoft corporation, Seattle, WA).

\section{Results}

Metabolism of 25-( $\mathrm{OH}) \mathrm{D}_{3}$ by renal cells in vitro. The three types of mammalian kidney cells studied were able to convert 25- $(\mathrm{OH}) \mathrm{D}_{3}$ into more polar metabolites. With LLC-PK 1 and rabbit's cells one of these metabolites eluting as a single peak coeluted with synthetic $1,25-(\mathrm{OH})_{2} \mathrm{D}_{3}$ on straight phase HPLC using a 92:8 n-hexane:isopropanol solvent (Fig. $1 A$ ) and using a 95:5 methylene chloride:isopropanol solvent (Fig. $1 B$ ). The amount of this metabolite found after $120 \mathrm{~min}$ of incubation in a $2 \mathrm{mM}$ phosphate medium with $5 \mathrm{nM}\left[{ }^{3} \mathrm{H}\right] 25-(\mathrm{OH}) \mathrm{D}_{3}$ ranged between 20 and $1100 \mathrm{fmol} / 10^{6}$ cells in rabbit's cell cultures (mean $=363 \mathrm{fmol} / 10^{6}$ cells, $n=10$ ), and between 40 and $500 \mathrm{fmol} / 10^{6}$ cells (mean $=151, n=8$ ) in LLC-PK 1 (Table I). The amount produced during 120 min incubation with $2 \mu \mathrm{M}$ $25-(\mathrm{OH}) \mathrm{D}_{3}$ ranged between 50 and 150 pmol/10 $10^{6}$ cells and was sufficient to show that the $1,25-(\mathrm{OH})_{2} \mathrm{D}_{3}$-like metabolite absorbed UV light, with a UV spectrum identical to that of synthetic $1,25-(\mathrm{OH})_{2} \mathrm{D}_{3}$ (maximal absorbance at $265.8 \mathrm{~nm}$, match angle $=3.851$ ), and that its ability to compete with the $\left[{ }^{3} \mathrm{H}\right] 1,25-(\mathrm{OH})_{2} \mathrm{D}_{3}$ for binding to the chick intestinal cytosol was identical to that of synthetic $1,25-(\mathrm{OH}) \mathrm{D}_{3}$ (Fig. 2). In contrast, with $\mathrm{OK}$ cells, the metabolite coeluting with synthetic 1,25- $(\mathrm{OH})_{2} \mathrm{D}_{3}$ in the first HPLC system (Fig. $1 \mathrm{C}$ ) did not coelute with the synthetic hormone in the second HPLC system (Fig. $1 D)$.

Effect of phosphate deprivation on 1,25- $(\mathrm{OH})_{2} \mathrm{D}_{3}$ synthesis. In vitro phosphate deprivation of cultured rabbit's kidney cells for $16 \mathrm{~h}$ increased their ability to produce $1,25(\mathrm{OH})_{2} \mathrm{D}_{3}$ (Fig. $3)$. The amount of $1,25(\mathrm{OH})_{2} \mathrm{D}_{3}$ produced after $120 \mathrm{~min}$ incubation was $3.8 \pm 1$. 1-fold higher (mean $\pm \mathrm{SE}, n=6$ ) in rabbit's 

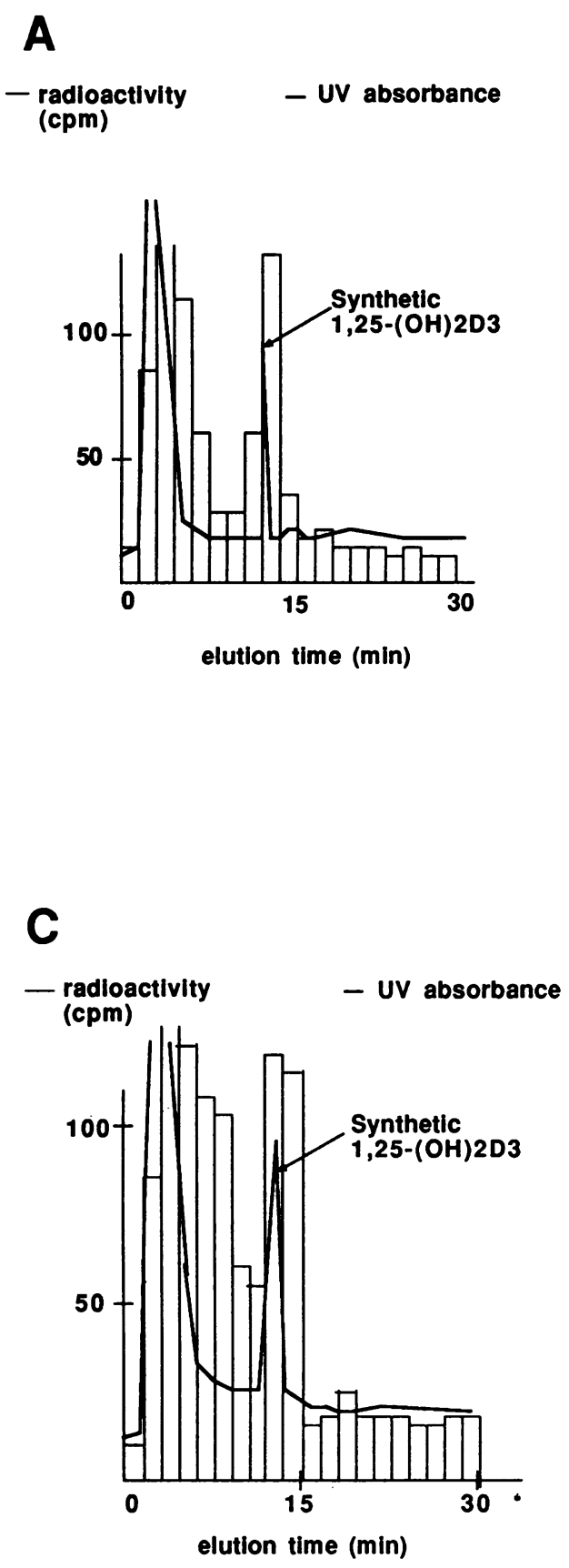

cells incubated in a phosphate free medium ( mean $=915$, range: $107-4220 \mathrm{fmol} / 10^{6}$ cells $)$ than in the presence of $2 \mathrm{mM}$ phosphate $\left(\right.$ mean $=272$, range: $20-1100 \mathrm{fmol} / 10^{6}$ cells $), P$ $=0.014$.

The stimulatory effect of phosphate depletion appeared to be related to a higher rate of $1,25(\mathrm{OH})_{2} \mathrm{D}_{3}$ production rather than to a decreased rate of $1,25(\mathrm{OH})_{2} \mathrm{D}_{3}$ catabolism, for it was observed as early as $30 \mathrm{~min}$ after the addition of $25(\mathrm{OH}) \mathrm{D}_{3}$ to the cell medium.

In LLC-PK 1 cells, partial phosphate depletion ( $1 \mathrm{mM})$ for $16 \mathrm{~h}$ led to a significant $(2.26 \pm$ fold $)$ stimulation of $1,25(\mathrm{OH})_{2} \mathrm{D}_{3}$ production, from 128 (range: $40-500$ ) fmol $/ 10^{6}$ cells $/ 120 \mathrm{~min}(n=7)$ to 231 (range: $62-650) \mathrm{fmol} / 10^{6} \mathrm{cells} /$

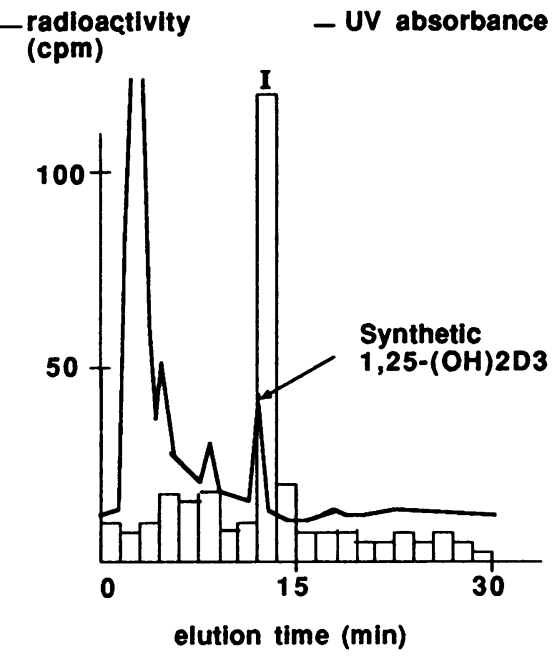

Figure 1. In vitro metabolism of $25(\mathrm{OH}) \mathrm{D}_{3}$ by mammalian kidney cells (rabbit's tubular cells in primary culture in Ham's F-12 and DMEM and OK cells in DMEM. Cells were incubated in a medium containing $2 \mathrm{mM}$ phosphate, with $50 \mathrm{nCi}\left({ }^{3} \mathrm{H}\right) 25(\mathrm{OH}) \mathrm{D}_{3} /$ well for $120 \mathrm{~min}$. After extraction, samples were cochromatographed with 100 ng nonlabeled $1,25(\mathrm{OH})_{2} \mathrm{D}_{3}$. $(A$ and $C$ ) The first HPLC used a $n$-hexane:isopropanol (92:8) solvent system (flow rate: $1,5 \mathrm{ml} /$ $\min )$. ( $B$ and $D$ ) The second HPLC used a methylene chloride:isopropanol (95:5) solvent system (flow rate: $1 \mathrm{ml} / \mathrm{min}$ ). In rabbit's cells the major metabolite (peak I) had the same elution position as synthetic $1,25(\mathrm{OH})_{2} \mathrm{D}_{3}$ using both solvent systems ( $A$ and $B$ ). In OK cells the peak (II) had the same elution position as synthetic $1,25(\mathrm{OH})_{2} \mathrm{D}_{3}$ using the first solvent system $(C)$ but not using the second one $(D)$.
$120 \min (n=7)$. In contrast, $1,25(\mathrm{OH})_{2} \mathrm{D}_{3}$ synthesis was not stimulated in cells submitted to more severe phosphate depletion $(0.5 \mathrm{mM})$ and $1,25(\mathrm{OH})_{2} \mathrm{D}_{3}$ was undetectable in cells submitted to total phosphate depletion (Fig. 4).

Effect of IGF 1 adjunction and adaptation to different extracellular concentrations of phosphate. Incubation of rabbit's cells with $25 \mathrm{ng} / \mathrm{ml}$ human IGF 1, for $16 \mathrm{~h}$, led to a limited and inconstant ( 3 out 5 experiments) increase in $1,25(\mathrm{OH})_{2} \mathrm{D}_{3}$ production when cells had been cultured in a serum and hormone free medium containing $2 \mathrm{mM}$ phosphate (Fig. 3). Yet, it had a marked stimulatory effect in cells incubated in a phosphate free medium. This effect was observed as early as $30 \mathrm{~min}$ after the addition of $25(\mathrm{OH}) \mathrm{D}_{3}$ to the medium (Fig. 3) and led 
Table I. $\left[{ }^{3} \mathrm{H}\right] 1,25(\mathrm{OH})_{2}$ Vitamin $\mathrm{D}_{3}$ Synthesized by Cultured Kidney Cells after a 120-min Incubation in a 2-mM Phosphate Medium in Presence of $5 \mathrm{nM}\left[{ }^{3} \mathrm{H}\right] 25(\mathrm{OH}) \mathrm{D}_{3}$

\begin{tabular}{lcc}
\hline & \multicolumn{2}{c}{$\begin{array}{c}{\left[{ }^{3} \mathrm{H}\right] 1,25(\mathrm{OH})_{2} \mathrm{D}_{3} \text { biosynthesized }} \\
\left(\mathrm{fmol} / 10^{6} \text { cells/120 min) }\right.\end{array}$} \\
\cline { 2 - 3 } \multicolumn{1}{c}{ Cellular type } & Mean (range) & Experiments \\
\hline OK & 0 & $n=5$ \\
LLC-PK1 & $151(40-500)$ & $n=8$ \\
Rabbit's tubular cells & $363(20-1100)$ & $n=10$ \\
\hline
\end{tabular}

to a 1.6-fold increase after $120 \mathrm{~min}$, from 915 (range: 1074220) $\mathrm{fmol} / 10^{6}$ cells $/ 120 \mathrm{~min}$ to 1670 (range: 101-7230) fmol $/ 10^{6}$ cells $/ 120 \min (n=5)$. Similarly, incubation of LLCPK 1 cells with $25 \mathrm{ng} / \mathrm{ml}$ human IGF 1 , for $16 \mathrm{~h}$, led to a limited, non significant increase in $1,25(\mathrm{OH})_{2} \mathrm{D}_{3}$ production

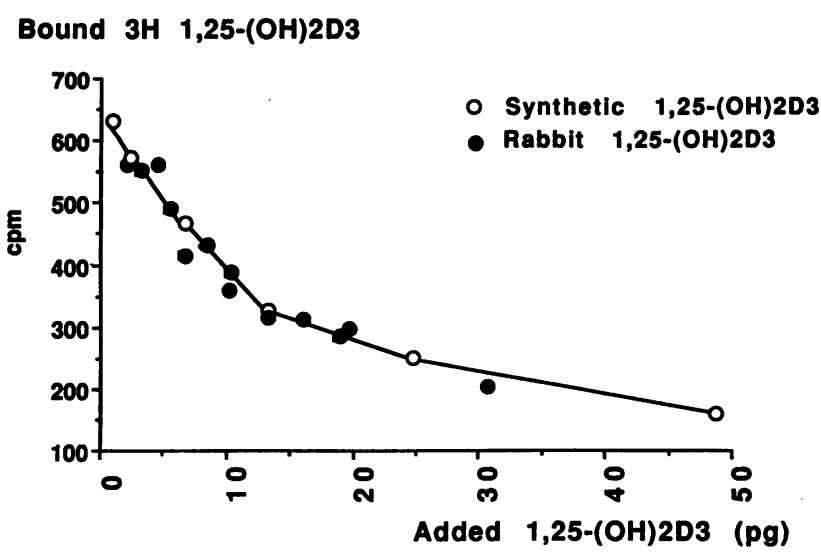

Bound 3H 1,25-(OH)2D3

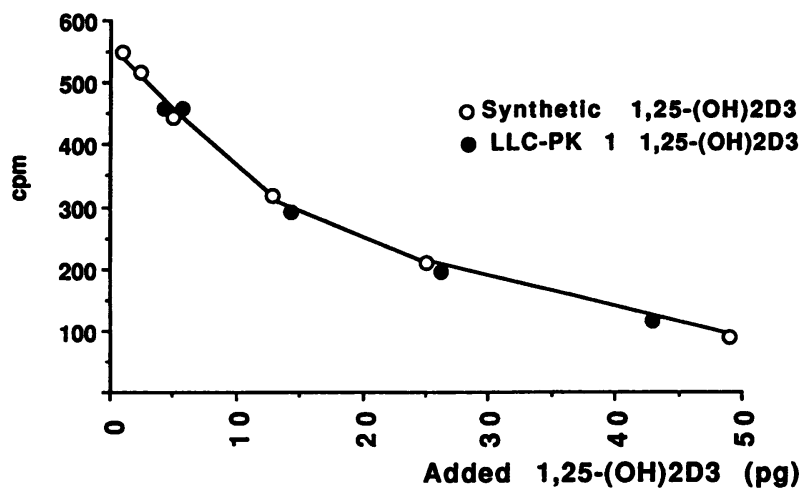

Figure 2. Ability of metabolites of $25(\mathrm{OH}) \mathrm{D}_{3}$ produced by mammalian kidney cells in culture to bind to $1,25(\mathrm{OH})_{2} \mathrm{D}_{3}$ receptors. Metabolites of nonlabeled $25(\mathrm{OH}) \mathrm{D}_{3}$ produced in vitro were purified by two successive HPLC, and the ability of various concentrations of these metabolites to compete with the binding of synthetic $\left({ }^{3} \mathrm{H}\right) 1,25(\mathrm{OH})_{2} \mathrm{D}_{3}$ to receptors present in chick intestinal cytosol was tested. Shown are synthetic $1,25(\mathrm{OH})_{2} \mathrm{D}_{3}(\mathrm{O})$ and metabolites produced by cultured cells $(\bullet)$. Rabbit's tubular cells on the top, and LLC-PK 1 on the bottom. Each closed circle represents the mean of two experiments performed in triplicate. Standard errors were $<5 \%$.

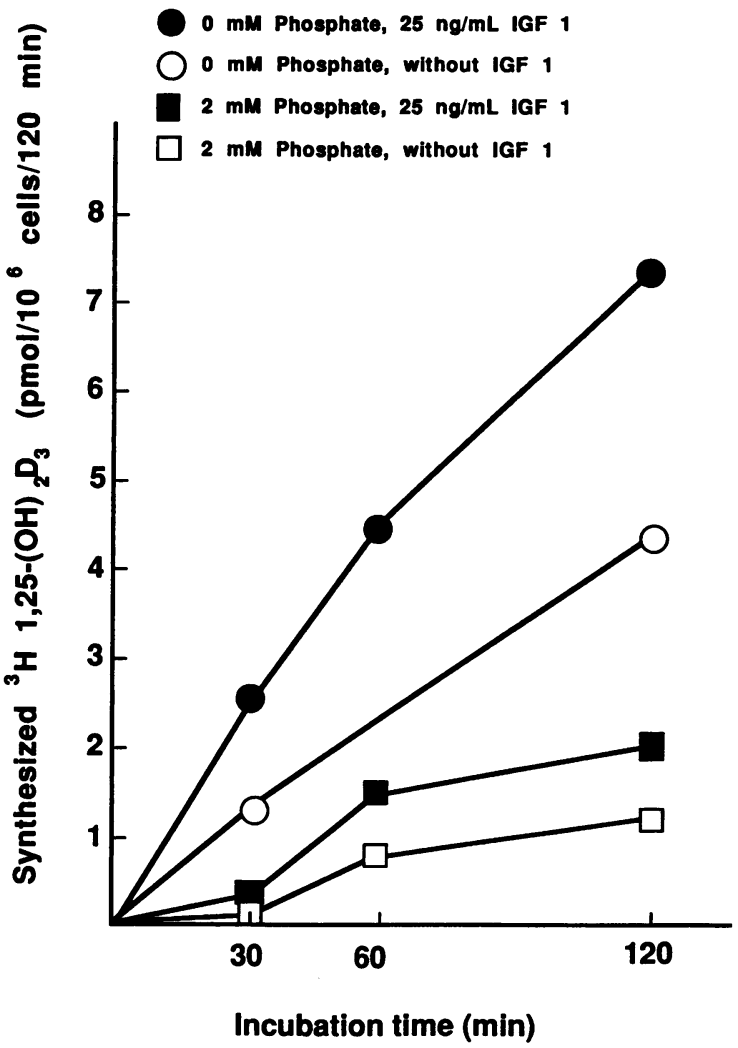

Figure 3. Effects of IGF 1 and medium phosphate concentration on $1,25(\mathrm{OH})_{2} \mathrm{D}_{3}$ synthesis in rabbit's tubular cells in primary culture. Time course: cells were incubated with $50 \mathrm{nCi}\left[{ }^{3} \mathrm{H}\right] 25(\mathrm{OH}) \mathrm{D}_{3} /$ well for 0 , 30,60 , and $120 \mathrm{~min}$. The experiments have been done after a 16-h preincubation in a $0 \mathrm{mM}$ phosphate medium (circles) or in a $2 \mathrm{mM}$ phosphate medium (squares), without (open) or with (closed) $25 \mathrm{ng} /$ ml IGF 1. Metabolites have been purified using two successive HPLC and the one with the same elution position as synthetic unlabeled $1,25(\mathrm{OH})_{2} \mathrm{D}_{3}$ in both systems has been quantified.

when cells had been cultured in a serum and hormone free medium containing $2 \mathrm{mM}$ phosphate, but to a marked increase in a partially phosphate depleted medium: 2.75 -fold in $1 \mathrm{mM}$ phosphate $(P=0.015, n=5)$ and 3.2-fold in $0.5 \mathrm{mM}$ phosphate $(P=0.043, n=4)$, (Fig. 4).

\section{Discussion}

We have shown that two types of mammalian kidney cells in culture (LLC-PK 1 and rabbit's tubular cells) are able to synthesize $1,25-(\mathrm{OH})_{2} \mathrm{D}_{3}$, and that this synthesis is modulated by local conditions, particularly extra-cellular phosphate concentrations and presence of IGF 1 in the medium.

Up to now several types of kidney cells have been studied in vitro for their ability to produce $1,25-(\mathrm{OH})_{2} \mathrm{D}_{3}$ : kidney cell homogenates, chick kidney cells in primary culture (33-38), and mammalian kidney cells $(15,39)$. With these cells, a direct effect of PTH, 1,25- $(\mathrm{OH})_{2} \mathrm{D}_{3}$, and calcitonin has been evidenced on 1,25-(OH $)_{2} \mathrm{D}_{3}$ production, but no direct effect of physiological doses of IGF 1, or phosphate depletion had yet been demonstrated. The rationale for using the three other cell types studied in the present work is the following: (a) OK cells, 


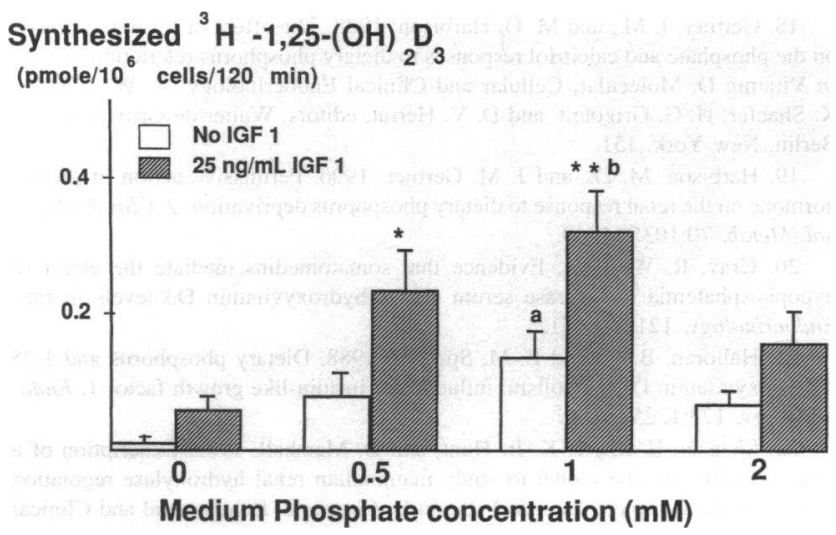

Figure 4. Effects of IGF 1 and phosphate concentration in culture medium on $1,25(\mathrm{OH})_{2} \mathrm{D}_{3}$ synthesis in LLC-PK 1 cells. The cells were preincubated for $16 \mathrm{~h}$ in various phosphate concentrations $(0,0.5,1,2$ $\mathrm{mM}$ ) without ( $\square$ ) or with ( $\square) 25 \mathrm{ng} / \mathrm{ml}$ IGF 1 . The cells were incubated with $50 \mathrm{nCi}\left[{ }^{3} \mathrm{H}\right] 25(\mathrm{OH}) \mathrm{D}_{3} /$ well for $120 \mathrm{~min}$. Metabolites of $\left[{ }^{3} \mathrm{H}\right]$ $25(\mathrm{OH}) \mathrm{D}_{3}$ have been purified using two successive HPLC and the one with the same elution position as synthetic $1,25(\mathrm{OH})_{2} \mathrm{D}_{3}$ in both systems has been quantified. Each bar represents the mean $\pm S E$ of four or five experiments. (*) Effect of IGF 1 in $0.5 \mathrm{mM}$ phosphate medium, $P$ $=0.043, n=4 ;\left(^{* *}\right)$ effect of IGF 1 in $1 \mathrm{mM}$ phosphate medium, $P$ $=0.015, n=5 ;(a)$ in comparison with $2 \mathrm{mM}$ phosphate, without IGF $1, P=0.038, n=5 ;(b)$ in comparison with $2 \mathrm{mM}$ phosphate, with IGF $1, P=0.013, n=5$.

obtained from an opossum kidney, were considered as tubular proximal cells because of their Pi uptake and are especially responsive to PTH, which decreases their Pi uptake and stimulates AMPc synthesis (40); (b) LLC-PK 1 cells, derived from a pig kidney, are known to express $1,25-(\mathrm{OH})_{2} \mathrm{D}_{3}$ receptors (41), and a 25-(OH) $\mathrm{D}_{3}-24-\mathrm{OH}$ ase responding to $1,25-$ $(\mathrm{OH})_{2} \mathrm{D}_{3}$, they also have a $\mathrm{Na}$ dependent-Pi uptake, but are non sensitive to PTH (40); (c) Rabbit's cells in primary culture are tubular proximal cells $(42,43)$ : they are epithelial, oriented with a brush border, they have $\mathrm{Na}$ dependent uptake of phosphate, glucose, and aminoacids and they express an AMPc response to PTH but not to calcitonin.

In our study, OK cells did not express an ability to synthesize $1,25(\mathrm{OH})_{2} \mathrm{D}_{3}$. This lack of expression may result from the conditions used in this study, or may be an argument in favor of the pars recta origin of the $\mathrm{OK}$ cells, as the $25-(\mathrm{OH}) \mathrm{D}_{3}$ $1 \alpha \mathrm{OHase}$ has been mainly localized in the proximal convoluted tubules in chick and rat kidneys (8). In contrast, LLC-PK 1 cells and rabbit's cells in primary culture expressed a clear 25 $(\mathrm{OH}) \mathrm{D}_{3}-1 \alpha \mathrm{OHase}$ activity, and thus proved to be new useful models for studying the $1 \alpha \mathrm{OHase}$ enzymatic system. Indeed, these cells proved to be able to convert $25-(\mathrm{OH}) \mathrm{D}_{3}$ into a metabolite which shared with $1,25-(\mathrm{OH})_{2} \mathrm{D}_{3}$ identical chromatographic properties on two HPLC systems, similar UV absorbance at $254 \mathrm{~nm}$, identical UV spectrum, and identical ability to compete with $\left[{ }^{3} \mathrm{H}\right] 1,25-(\mathrm{OH})_{2} \mathrm{D}_{3}$ for binding to the chick intestinal cytosol. The only vitamin $\mathrm{D}$ metabolite known to meet these criteria is $1,25-(\mathrm{OH})_{2} \mathrm{D}_{3}(32,44)$. These results also show that the ability to synthesize $1,25-(\mathrm{OH})_{2} \mathrm{D}_{3}$ and the sensitivity to PTH (cAMP dependent) do not necessarily coexist in the same cultured renal cell line. LLC-PK 1 cells were able to produce $1,25(\mathrm{OH})_{2} \mathrm{D}_{3}$ in our experimental conditions but are known not to be responsive to PTH, while OK cells were unable to synthesize $1,25(\mathrm{OH})_{2} \mathrm{D}_{3}$ but are responsive to PTH (40).

Using these mammalian cell models, we were able to show a local effect of phosphate and IGF 1. Phosphate plays a physiological role in the regulation of serum concentration of $1,25(\mathrm{OH})_{2} \mathrm{D}_{3}$ : oral intake and serum concentration of phosphorus alter serum concentration of $1,25(\mathrm{OH})_{2} \mathrm{D}_{3}$ and its production rate $(12,13)$, via a possibly GH- or IGF 1 -dependent mechanism $(16-21,45)$. The results of our study provide the first evidence of a local action of phosphate concentration on $1,25(\mathrm{OH})_{2} \mathrm{D}_{3}$ production, not requiring exogenous IGF I: total phosphate depletion in rabbit's kidney cells and partial phosphate depletion in LLC-PK 1 had a clear stimulating effect on $1,25(\mathrm{OH})_{2} \mathrm{D}_{3}$ production. Trechsel et al. (14) in 1979 did not evidence this effect of phosphate depletion while studying cultured chick kidney cells. Two main differences in the experimental protocols may explain these discrepancies: differences in the species origin of the cells, or the use by Trechsel et al. (14) of a medium enriched with $10 \%$ FCS which may have masked the phosphate effect, while we used a serum and hormone-free medium. Fukase et al. (15) in 1982 found an inhibitory effect of high phosphate concentrations on the ability of the mouse kidney cells to produce $1,25(\mathrm{OH})_{2} \mathrm{D}_{3}$, but did not detect any effect of phosphate depletion (15). They concluded that the effect of phosphate deprivation is only indirect. But they used an insulin $(5 \mu \mathrm{g} / \mathrm{ml})$ enriched medium to study $1 \alpha \mathrm{O}$ Hase and an interaction between this hormone and phosphate can not be excluded.

While partial phosphate depletion ( $1 \mathrm{mM})$ of LLC-PK 1 cells stimulated their ability to produce $1,25(\mathrm{OH})_{2} \mathrm{D}_{3}$, total phosphate depletion led to an almost complete loss of this ability. Complete phosphate depletion can deeply affect cell metabolism and the phosphorylation-dephosphorylation pathway regulating $25-(\mathrm{OH}) \mathrm{D}_{3}-1 \alpha \mathrm{OH}$ ase activity. Previous studies reported that LLC-PK 1 cells cultured in a phosphate free medium exhibit an increase of $\mathrm{Na}$ dependent phosphate uptake, an unaltered ATPase but a sharp decrease of intracellular phosphate and ATP (46).

IGF 1 is thought to be the messenger of phosphate depletion. In vivo studies have shown its action on phosphate mediated control of $1,25(\mathrm{OH})_{2} \mathrm{D}_{3}$ production $(20,21,45)$. But up to now, the only reported in vitro stimulating effect of IGF 1 on $1,25(\mathrm{OH})_{2} \mathrm{D}_{3}$ production was obtained with a pharmacological concentration of Somatomedin C by Spencer et al. (22). Our results clearly show that low concentrations of exogenous IGF 1 can stimulate $1,25(\mathrm{OH})_{2} \mathrm{D}_{3}$ synthesis. This effect has not been evidenced before, probably because of the media that were used: they contained serum (and therefore IGF and IGF BPs), or insulin (which can saturate IGF 1 receptors). In keeping with what has been observed after its in vivo administration (47), IGF 1 added directly in vitro had only a limited effect on $1,25(\mathrm{OH})_{2} \mathrm{D}_{3}$ synthesis when phosphate was at a normal level, but had a marked effect when phosphate concentration in the medium was low. Thus, IGF 1 appears to be an important regulator of the adaptation of $1,25(\mathrm{OH})_{2} \mathrm{D}_{3}$ synthesis to phosphate deprivation, although such adaptation does not require the presence of exogenous IGF 1.

Phosphate concentration and IGF 1 may act at different levels on the $1 \alpha \mathrm{OH}$ ase system. Phosphate depletion may directly enhance dephosphorylation of the ferredoxin, thus activating the $1 \alpha$ OHase $(48,49)$. IGF 1 may potentiate the phos- 
phate depletion effect through direct action on phosphate captation (50-52). It may also stimulate the synthesis of the cytochrome P450 component of the enzyme complex. It may finally affect dephosphorylation of the ferredoxin through a PKC mediated pathway (53).

Whatever the mechanism involved, this first demonstration of a local effect of IGF 1 on $1,25(\mathrm{OH})_{2} \mathrm{D}_{3}$ synthesis suggests that IGF 1 can have a double function during growth: not only of accelerating growth, but also of increasing bone mineralization through regulation of $1,25(\mathrm{OH})_{2} \mathrm{D}_{3}$ production.

\section{Acknowledgments}

We gratefully acknowledge Jacques Hervagault and Sophie Bertaux (Millipore/Continental Water Systems) for help in performing UV spectroscopy. We also thank Jacques Boulle for help in language and style.

This work was supported in part by grants from La Fondation pour la Recherche Médicale, 54 rue de Varenne, Paris, France, from Guigoz, 12 rue de l'industrie, Courbevoie, France, and from La Société d'Etudes et de Soins pour les Enfants Paralysés et polymalformés, Château de Longchamp, bois de Boulogne, Paris, France.

\section{References}

1. Kumar, R. 1986. The metabolism and mechanism of action of 1,25-dihydroxyvitamin D3. Kidney Int. 30:793-803.

2. Rosen, J. F., and R. W. Chesney. 1983. Circulating calcitriol concentrations in health and disease. J. Pediatr. 103:1-17.

3. Chesney, R. W., J. F. Rosen, A. J. Hamstra, and H. F. DeLuca. 1980. Serum 1,25- $(\mathrm{OH})_{2}$ vitamin $\mathrm{D}$ levels in normal children and in vitamin $\mathrm{D}$ disorders. Am. J. Dis. Child. 134:135-139.

4. Lund, B., N. Chausen, B. Lund, E. Andersen, and O. H. Soresen. 1980. Age-dependent variations in serum 1,25 dihydroxy-vitamin D in childhood. Acta Endocrinol. (Copenh). 94:426-429.

5. Aksnes, L., and D. Aarskog. 1982. Plasma concentrations of vitamin D metabolites in puberty: effect of sexual maturation and implications for growth. J. Clin. Endocrinol. Metab. 55:94-99.

6. DeLuca H. F. 1978. Vitamin D metabolism and fonction. Arch. Intern. Med. 138:836-847.

7. Fraser, D. R. 1980. Regulation of the metabolism of vitamin D. Physiol. Rev. 60:551-613.

8. Kawashima, H., and K. Kurokawa. 1986. Metabolism and sites of action of vitamin D in the kidney. Kidney Int. 29:98-107.

9. Breslau, N. A. 1988. Normal and abnormal regulation of $1,25-(\mathrm{OH})_{2} \mathrm{D}$ synthesis. Am. J. Med. Sci. 296:417-425.

10. Reichel, H., H. P. Koeffler, and A. W. Norman. 1989. The role of the vitamin D endocrine system in health and disease. N. Engl. J. Med. 320:980991.

11. Garabédian, M., M. F. Holick, H. F. DeLuca, and I. T. Boyle. 1972. Control of 25-hydroxycholecalciferol metabolism by the parathyroid glands. Proc. Natl. Acad. Sci. USA. 69:1673-1676.

12. Portale, A. A., B. P. Halloran, M. M. Murphy, and R. C. Morris, Jr. 1986. Oral intake of phosphorus can determine the serum concentration of 1,25 dihydroxy-vitamin D by determining its production rate in humans. J. Clin. Invest. 77:7-12.

13. Portale, A. A., B. P. Halloran, and R. C. Morris. 1989. Physiologic regulation of serum concentration of 1,25-dihydroxyvitamin D by phosphorus in normal men. J. Clin. Invest. 83:1494-1499.

14. Trechsel, U., J. P. Bonjour, and H. Fleisch. 1979. Regulation of the metabolism of 25-hydroxyvitamin D3 in primary cultures of chick kidney cells. J. Clin. Invest. 64:206-217.

15. Fukase, M., S. J. Birge, Jr., L. Rifas, L. V. Avioli, and L. R. Chase. 1982. Regulation of hydroxy vitamin D3 1-hydroxylase in serum-free monolayer culture of mouse kidney. Endocrinology. 110:1073-1075.

16. Gray, R. W., T. L. Garthwaite, and L. S. Phillips. 1983. Growth hormone and triiodothyronine permit an increase in plasma 1,25(OH)2 D concentrations in response to dietary phosphate deprivation in hypophyzectomised rats. Calcif. Tissue Int. 35:100-106.

17. Gray, R. W., and T. L. Garthwaite. 1985. Activation of renal 1,25-dihydroxy vitamin D3 synthesis by phosphate deprivation: evidence for a role for growth hormone. Endocrinology. 116:189-193.
18. Gertner, J. M., and M. D. Harbison. 1988. The effect of growth hormone on the phosphate and calcitriol responses to dietary phosphorus restriction in man. In Vitamin D, Molecular, Cellular and Clinical Endocrinology. A. W. Norman, K. Shaefer, H. G. Grigoleit, and D. V. Herrat, editors. Walter de Gruyter \& Co., Berlin, New York. 151

19. Harbison, M. D., and J. M. Gertner. 1990. Permissive action of growth hormone on the renal response to dietary phosphorus deprivation. J. Clin. Endocrinol. Metab. 70:1035-1040.

20. Gray, R. W. 1987. Evidence that somatomedins mediate the effect of hypophosphatemia to increase serum 1,25 dihydroxyvitamin D3 levels in rats. Endocrinology. 121:504-512.

21. Halloran, B. P., and E. M. Spencer. 1988. Dietary phosphorus and 1,25 dihydroxyvitamin D metabolism: influence of insulin-like growth factor 1. Endocrinology. 123:1225-1229.

22. Spencer, E. M., T. K. Jr. Hunt, and D. Marshall. 1982. Description of a new, versatile porcine model to study mammalian renal hydroxylase regulation in vitro in the D replete state. In Vitamin D, Chemical, Biochemical and Clinical Endocrinology of Calcium Metabolism. A. W. Norman, K. Scheafer, D. V. Herrath, and H. G. Grigoleit, editors. Walter de Gruyter \& Co., Berlin, New York. 507-509.

23. Koyama, H., H. C. Goodpasture, M. M. Miller, R. L. Replitz, and A. D. Riggs. 1978. Establishment and characterization of a cell line from an american opossum. In vitro. 14:239-246.

24. Friedlander, G., S. Couette, C. Coureau, and C. Amiel. 1992. Mechanisms whereby extracellular adenosine $3^{\prime}, 5^{\prime}$-monophosphate inhibits phosphate transport in cultured opossum kidney cells and in rat Kidney. J. Clin. Invest. 90:848858.

25. Friedlander, G., M. Shahedi, C. Le Grimellec, and C. Amiel. 1988. Increase in membrane fluidity and opening of tight junctions have similar effects on sodium-coupled uptakes in renal epithelial cells. J. Biol. Chem. 263:11183-11188.

26. Bello-Reuss, E., and M. R. Weber. 1986. Electrophysiological studies on primary cultures of proximal tubule cells. Am. J. Physiol. 251:F403-F411.

27. Friedlander, G., and C. Amiel. 1989. Protein kinase $\mathrm{C}$ activation has dissimilar effects on sodium-coupled uptakes in renal proximal tubular cells in primary culture. J. Biol. Chem. 264:3935-3941.

28. Vinay, P., A. Gougoux, and G. Lemieux. 1981. Isolation of a pure suspension of rat proximal tubules. Am. J. Physiol. 241:F403-F411.

29. Steele, R. E., A. S. Preston, J. P. Johnson, and Handler. 1986. Porous bottom dishes for culture of polarized cells. Am. J. Physiol. 251:C136-139.

30. Chuman, L., L. G. Fine, A. H. Cohen, and M. H. Saier, Jr. 1982. Continuous growth of proximal tubular kidney epithelial cells in hormone-supplemented serum-free medium. J. Cell Biol. 94:506-510.

31. Bligh, E. G., and W. J. Dyer. 1959. A rapid method of total lipid extraction and purification. Can. J. Biochem. Physiol. 37:911.

32. Shepard, R. M., R. L. Horst, A. J. Hamstra, and H. F. DeLuca. 1979. Determination of vitamin $\mathrm{D}$ and its metabolites in plasma from normal and anephric man. Biochem. J. 182:55-69.

33. Henry, H. L. 1977. Metabolism of 25-hydroxyvitamin D3 by primary cultures of chick kidney cells. Biochem. Biophys. Res. Commun. 74:768-75.

34. Henry, H. L. 1979. Response of chick kidney cell cultures to 1,25-dihydroxy-vitamin D3. In Vitamin D, basic research and its clinical application. A. W. Norman, K. Schaefer, D. V. Herrath, H. G. Grigoleit, J. W. Coburn, H. F. DeLuca, E. B. Mawer, and T. Suda, editors. Walter de Gruyter \& Co., Berlin, New York. 467-474.

35. Henry, H. L. 1981. Insulin permits parathyroid hormone stimulation of 1,25-dihydroxyvitamin D3 production in cultured kidney cells. Endocrinology. 108:733-735.

36. Henry, H. L., T. A. Noland, Farad Al-Abdaly, N. S. Cunningham, E. M. Luntao, and L. D. Amdahl. 1982. Responses of cultured chick cells to parathyroid hormone and calcitonin. In Vitamin D, chemical, biochemical and clinical endocrinology of calcium metabolism. A. W. Norman, K. Schaefer, H. G. Grigoleit, and D. V. Herrath, editors. Walter de Gruyter \& Co., Berlin, New York. 533538.

37. Henry, H. L., E. M. Luntao, C. Dutta, N. S. Cunningham, and S. R. Kain. 1988. Current models for the study of the regulation of 25(OH)D3 metabolism. In Vitamin D, molecular, cellular, and clinical endocrinology. A. W. Norman, $\mathrm{K}$ Schaefer, H. G. Grigoleit, and D. V. Herrath, editors. Walter de Gruyter \& Co., Berlin, New York. 157-165.

38. Spanos, E., D. I. Barret, K. T. Chong, and I. MacIntyre. 1978. Effect of oestrogen and 1,25-dihydroxycholecalciferol metabolism in primary chick kidney cell culture. Biochem. J. 174:231-236.

39. Juan, D., and H. F. DeLuca. 1977. The regulation of 24,25-dihydroxyvitamin D3 production in cultures of monkey kidney cells. Endocrinology. 101:11841193. 215.

40. Handler, J. S. 1986. Studies of kidney cells in culture. Kidney Int. 30:208-

41. Colston, K., and D. Feldman. 1982. 1,25-Dihydroxyvitamin $D_{3}$ receptors 
and fonctions in cultured pig kidney cells $\left(\mathrm{LLC} \mathrm{PK}_{1}\right)$. J. Biol. Chem. 257:25042508.

42. Chung, S. D., N. Alavi, D. Livingston, S. Hiller, and M. Taub. 1982. Characterization of primary rabbit kidney cultures that express proximal tubule functions in a hormonally defined medium. J. Cell Biol. 95:118-126.

43. Fine, L. G., and L. M. Sakhrani. 1986. Proximal tubular cells in primary culture. Miner. Electrolyte Metab. 12:51-57.

44. Mayer, E., J. E. Bishop, N. Ohnuma, and A. W. Norman. 1983. Biological activity assessment of the vitamin D metabolites 1,25-dihydroxy-24-oxo-vitamin D3 and 1,23,25-trihydroxy-24-oxo-vitamin D3. Arch. Biochem. 224:671-676.

45. Spencer, E. M., and B. P. Halloran. 1988. The stimulation of 25-hydroxyvitamin D-1-hydroxylase by dietary phosphorus restriction requires insulin-like growth factor 1 (IGF 1). In Vitamin D, molecular, cellular and clinical endocrinology. A. W. Norman, K. Schaefer, H. G. Grigoleit, and D. V. Herrath, editors. Walter de Gruyter \& Co., Berlin, New York. 174-176.

46. Escoubet, B., B. Djabali, and C. Amiel. 1989. Adaptation to Pi deprivation of cell Na-dependent Pi uptake: a widespread process. Am. J. Physiol. 256:C322C328.

47. Nesbitt, T., and M. K. Drezner. 1993. Insulin-Like Growth Factor-I regulation of renal 25-hydroxyvitamin D-1-hydroxylase activity. Endocrinology. 132:133-138.

48. Ghazarian, J. G. 1990. The renal mitochondrial hydroxylases of the vitamin
$\mathrm{D}_{3}$ endocrine complex: how are they regulated at the molecular level? J. Bone Miner. Res. 5:897-903.

49. Ghazarian, J. G., M. L. Mandel, and B. Moorthy. 1991. $\mathrm{Ca}^{2+}$-calmodulinactivated protein kinase in structurally intact kidney mitochondria phosphorylates the endogenous ferredoxin: modulation of $1 \alpha$ - and 24-hydroxylases of 25-hydroxyvitamin $D_{3}$. In Vitamin D, Gene Regulation, Structure Function Analysis and Clinical Application. A. W. Norman, R. Bouillon, and M. Thomasset, editors. Walter de Gruyter \& Co., Berlin, New York. 261-262.

50. Caverzasio, J., and J. P. Bonjour. 1989. Insulin-like growth factor I stimulates Na-dependent $\mathrm{Pi}$ transport in cultured kidney cells. Am. J. Physiol. 257:F712-F717.

51. Caverzasio, J., C. Montessuit, and J. P. Bonjour. 1990. Stimulatory effect of insulin-like growth factor-1 on renal Pi transport and plasma 1,25 dihydroxyvitamin D3. Endocrinology. 127:453-459.

52. Quigley, R., and M. Baum. 1991. Effects of growth hormone and insulinlike growth factor I on rabbit proximal convoluted tubule transport. J. Clin. Invest. 88:368-374.

53. Weaver, V. M., D. J. Franks, and J. E. Welsh. 1991. Activation of protein kinase $\mathrm{C}$ modulates dihydrocholecalciferol synthesis in rat renal proximal tubules. In Vitamin D, Gene Regulation, Structure Function Analysis and Clinical Application. A. W. Norman, R. Bouillon, and M. Thomasset, editors. Walter de Gruyter \& Co., Berlin, New York. 275-276. 